\title{
A Library Credit Course and Student Success Rates: A Longitudinal Study
}

\section{Jean Marie Cook}

\begin{abstract}
The University of West Georgia's Ingram Library has offered a fifteen-week two-hour credit course since 1998. In a longitudinal study covering twelve years, the library analyzed the progression and graduation rates of more than fifteen thousand students. Students who took the class during their undergraduate career were found to graduate at much higher rates than students who never took the class. The library examined students' high school GPAs and aptitude test scores but were unable to account for the increase through any difference in precollegiate achievement.
\end{abstract}

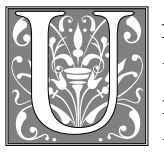

nder calls from the president to increase college graduation rates and nationwide initiatives such as the Complete College America program, colleges and universities are responding to an increasing pressure to improve student success rates. They use empirical and quantitative data to demonstrate their success in increasing student achievement to both politicians and the public. They dedicate time and resources to people and programs that are shown likely to improve their retention, progression, and graduation (RPG) rates. Opportunities abound for departments that can demonstrate they make a difference, but most libraries struggle to describe precisely how they can affect an individual student's likelihood to graduate. In their 2010 report, The Value of Academic Libraries, the Association of College and Research Libraries (ACRL) acknowledged this difficulty by creating a "Research Agenda" to guide libraries in establishing their value. ${ }^{1}$ They asked the essential question, "How does the library contribute to student retention and graduation rates?" which specifically called for correlative studies of library credit courses and graduation rates. ${ }^{2}$ This study seeks to address that question.

Ingram Library, at the University of West Georgia, struggled with trying to measure its impact on student success rates. While the library did offer oneshots, and the library itself was one of the busiest buildings on campus, it was difficult to definitively link library use to students' success in their classes. The library also offered a semester-long credit course focusing on information literacy skills. This course, entitled LIBR 1101 Academic Research and the Library, even fell within the university's core curriculum and hence counted toward students' final degrees. Librarians had gathered a great deal of anecdotal evidence about how much students liked the course and would use it in the future. However, the actual academic influence of this course was hard to establish. When the university began channeling funding and other 
resources toward initiatives to increase student achievement, the library undertook a comprehensive longitudinal study to determine what, if any, was the impact of the library credit course on student success rates.

\section{Literature Review}

Much of the literature on the assessment of library instruction focuses on measuring the improvement of student skills. Many researchers have used pre- and post-tests to determine their success in this area $\left(\right.$ Wood $^{3}$; Germain, Jacobson, and Kaczor ${ }^{4}$; Staley, Branch, and Hewitt Swoger $\left.{ }^{6}\right)$. Others focus on the application of skills in student work through methods like citation analysis (Joswick ${ }^{7}$; Hovde $^{8}$; Silfen and Zgoda9; Brunvand and Pashkova-Balkenhol ${ }^{10}$ ). However, by concentrating on assessing the immediate advancement of student skills, these same studies do not consider the potential long-term impact of library instruction. That is, do students remember and continue to use these skills after the course is completed? Does having these skills make any impact on the student's overall collegiate success?

Several studies have suggested that the library instruction has a lasting impact on students' behavior and ultimate success. Daugherty and Russo conducted a survey of students who had completed their school's library credit course within the last three academic years. ${ }^{11}$ While most of their respondents had taken the course within a year of the study, the majority of the students did say that they had used the skills learned in the class for research projects in other courses. ${ }^{12}$ Lebbin found that students who participated in learning communities that was focused on the academic library reported that they too used their new skills in "a variety of other courses."13 Person also found that students who completed a library course were more confident using the library, and the majority of his respondents had used their skills in other classes. ${ }^{14}$ Hardesty, Lovrich, and Mannon discovered that exposure to library instruction was much more highly correlated with proficiency in library skills than students' SAT scores or GPAs. ${ }^{15}$

Other researchers have focused on using quantitative analysis to determine the impact of library instruction. Wong and $\mathrm{Cmor}$ found that offering more workshops to degree programs on campus correlated with higher average GPAs for students in that program. ${ }^{16}$ Wang published a study of citations in nonlibrary classes, comparing the work of students who had taken a library credit course previously to those who had not. ${ }^{17}$ Even though the average time since completing the library course was about one academic year, students who had credit for the course had significantly better citations and scored significantly better grades on their papers and in the overall class grades. ${ }^{18}$ Selegean, Thomas, and Richman directly compared the students in their library credit course against students without the course who had similar majors, grade levels, and SAT scores. ${ }^{19}$ They found that students who completed the course had significantly higher GPAs and persistence rates, though there was no difference in the graduation rates. ${ }^{20}$ At Hofstra University, librarians framed several freshman learning communities around a library course and found that their students were retained to the second year at higher rates than other freshmen, including those students who participated in other freshman learning communities. ${ }^{21}$

\section{Background}

In 1998, the University System of Georgia's Board of Regents directed every college to adopt fifteen-week semesters and a standardized core curriculum. While certain areas such as math, English, and science were mandated, each university could define one area of the new core with its own local priorities. The University of West Georgia (UWG) declared these priorities to be communication, critical thinking, and twenty-first century technology. Sensing an opportunity, the 
university's Ingram Library expanded a former one-hour nine-week course into a fifteen-week two-hour course called LIBR 1101, Academic Research and the Library. This course was then entered into the core curriculum as one of several options that students could use to fulfill the Institutional Priorities requirement.

Throughout the next ten years, the class was offered in face-to-face and online formats. As early as fall 2001, the class could be taken 100 percent online. While there was a standard course description and objectives, instructors were allowed to customize their particular delivery and curriculum. Generally the course covered the different types of sources that the library offered, how to find those resources, and techniques to properly evaluate and use them. In 2007, the library reworded its course objectives to bring them in line with the ACRL Information Literacy Competency Standards for Higher Education. $^{22}$

At the same time, UWG as a whole was growing. Around 2008, it began a series of initiatives to improve the retention, progression, and graduation rates of its students. Resources, in both finances and staff time, were increasingly being routed to support these initiatives. Library faculty members who served on the planning committees for these programs were struck by a perceived lack of interest in the library's role to support students. The library did not have a major and, beyond a single course offered each semester, was not actively producing graduates. The library became interested in attempting to demonstrate quantitatively its impact and implemented a longitudinal study of students who had taken the course.

\section{Methodology}

At this study's inception, UWG's measures for success focused on students who entered college as first-time, fulltime (FTFT) freshmen. That is, they only considered the RPG rates of those fulltime students who were entering UWG during the fall semester of each year and who had never taken traditional college courses before. It is important to note that this population leaves out large segments of the university's students, including many students who did take LIBR 1101 during the study's time frame. Excluded populations include part-time students, transfer students, students who began in the summer or spring semesters, and students who were returning to college after a long absence. Since any findings from this study would be directly compared to the university's official metrics, the library also began with the each class's entire FTFT freshman pool as a sample population. By excluding those students who did not fall into this sample, the study results would be more relevant to external, on-campus stakeholders.

UWG's Department of Institutional Research and Planning provided information on each FTFT class from fall 1999 through summer 2011. To avoid privacy concerns, the library chose to only review aggregate data for each class. By concentrating on progression and graduation rates, the library hoped to demonstrate its effect on student collegiate success as a whole. Therefore, the study was restricted to the FTFT class for each year between 1999 and 2007. For each class, the students in it were divided into two cohorts: those who had taken LIBR 1101 at some point during their collegiate career and those who had not. The LIBR 1101 cohort includes those students who took LIBR 1101 face-to-face and those who took it online. All 15,012 FTFT students who entered UWG between 1999 and 2007 were included in this study.

For each class that began in fall 1999 through fall 2007, the total populations and four-, five-, and six-year graduation rates of each cohort were culled from the campus databases. These graduation rates included only those students from the initial FTFT population who graduated from UWG before summer of the given deadline. For instance, to be included in fall 2000's four-year graduation rate, students must have completed their degrees 
by the summer 2004 graduation deadline. It should be noted that these metrics do not quite represent the school's achievements. Not every student who failed to graduate from UWG dropped out of college. The University of West Georgia is part of a university system that encourages transferability between schools. Many students choose to attend their local regional schools for the core curriculum before transferring to complete their degree. Other students may take longer than the prescribed six years to graduate. Also, this graduation rate does not include all those transfer and nontraditional students who were excluded from the initial FTFT population. Finally, the study included the total number of students from each cohort who had graduated by summer 2011, as well as their average GPAs at graduation.

This study is an observational study. The library course is only one of several choices student have to complete the Institutional Priorities area of the core curriculum. Since enrollment in the course was by self-selection, the LIBR 1101 cohorts were not a random or representative sample of the FTFT students of each year. The library wanted to determine whether students who opt to take a library course are more likely to succeed. Hence, for each FTFT class that began in fall 1999 through fall 2007, the library also pulled the average SAT-Verbal (SATV), SATMath (SATM), ACT, and high school GPA scores of the LIBR1101 and non-LIBR1101 cohort. These are the same metrics UWG used to predict student success and would again allow the library to compare its results to the university as a whole.

For each FTFT cohort, the library then completed a series of statistical tests to determine the relationship, if any, between library instruction and student success rates. The study began with a series of Pearson Chi-Square $\left(\chi^{2}\right)$ Tests for Independence to determine the existence of a statistical correlation between the graduation rates and taking the course. The Pearson Chi-Square Test is appropriate, since the independent variables (taking the class or not) and dependent variables (graduating or not) were nonoverlapping categories. While the samples are not random, because students self-selected the course, they are not truly samples either. In each year, the cohort of LIBR 1101 students included all students from that year who took the course at some point during their collegiate career. The other cohort included every student who did not take the course. Together, they represented the total population of each FTFT class. Hence, this statistic can still be used for analysis purposes, but researchers must be careful in generalizing its results.

For each graduation milestone, a Pearson Chi-Square was constructed for each year. The null hypothesis $\left(\mathrm{H}_{\mathrm{o}}\right)$ in each case was: In the first-time, full-time population of this year, there is no association between taking the course and graduating in four years. The alternate hypothesis $\left(\mathrm{H}_{\mathrm{a}}\right)$ then was: In the first-time, full-time population of this year, there is an association between taking the course and graduating in four years. For the five- and six-year graduation tests, each hypothesis was altered accordingly. The study also included a Pearson Chi-Square test for total graduation rates from each class. The common statistical level of significance of $\alpha=.05$ was used as the threshold for rejecting the null hypothesis in all these tests.

The library also considered the student's GPA at time of college graduation. For this test, an average was taken of the GPAs of all students from each cohort who had graduated prior to summer 2011. Then the average graduation GPA of those who had taken the course was compared to the average graduation GPA of those who had not taken the course for each year. The library used a series of two-sample z-tests for the difference between means, since the population size for all graduating classes was sufficiently large $(n>30)$. Here, the null hypothesis $\left(\mathrm{H}_{\mathrm{o}}\right)$ was: For 
the FTFT population of this year, there is no difference in the average college graduation GPA of students who took the class and students who did not take the class. The alternate hypothesis $\left(\mathrm{H}_{\mathrm{a}}\right)$ then was: For the FTFT population of this year, there is a difference between the average college graduation GPA of students who took the class and those who did not. Again, the threshold level of significance was $\alpha=.05$.

Finally, the library used another series of two-sample z-tests to determine any difference in high school graduation GPAs and ACT, SATV, and SATM scores. Similar to the college graduation GPA tests, the null hypotheses would follow the guidelines of: For the FTFT population of this year, there is no difference in the average ACT score for students who did and did not take the library course. The alternative hypotheses were: For the FTFT population of this year, there is a difference in the average ACT score for students who did and did not take the library course.

\section{Results}

For the four-year graduation tests, the null hypothesis was rejected seven out of nine years (see table 1). That is, students graduating from the college in four years were positively associated with students who took the course during their time at the school for seven of the nine years in the study. In the two years where there was not a statistically significant correlation (2005 and 2007), students in the class still graduated at higher rates than those who didn't take the course. For the fiveyear graduation tests, the null hypothesis was rejected eight out of eight years (see table 2). For the six-year graduation tests, the null hypothesis was again rejected seven out of seven years (see table 3 ). Finally, for the total graduation tests, the null hypothesis was rejected eight out of the nine years (see table 4 ). The only year that did not reject the null hypothesis was the 2007 class, whose total graduation rate only includes those who graduated in four years. Hence, while four-year graduation rates may or may not show an

\begin{tabular}{|c|c|c|c|c|c|}
\hline \multicolumn{6}{|c|}{$\begin{array}{l}\text { TABLE } 1 \\
\text { Four Year Graduation Rates for FTFT Students }\end{array}$} \\
\hline \multirow[t]{2}{*}{ Year } & \multicolumn{2}{|c|}{$\begin{array}{l}\text { Students Who Took the } \\
\text { Library Course }\end{array}$} & \multicolumn{2}{|c|}{$\begin{array}{l}\text { Students Who Did Not } \\
\text { Take the Library Course }\end{array}$} & \multirow{2}{*}{\begin{tabular}{|c|} 
Statistical Analysis \\
$p=$ Probability of Wrongly \\
Rejecting $\mathrm{H}_{\mathrm{o}}$ When It Is True
\end{tabular}} \\
\hline & Population & $\begin{array}{l}\text { Graduation } \\
\text { Rate }(\%)\end{array}$ & Population & $\begin{array}{l}\text { Graduation } \\
\text { Rate }(\%)\end{array}$ & \\
\hline 1999 & 295 & 15.93 & 1,303 & 7.14 & Reject $\mathrm{H}_{\mathrm{o}}(p<0.0001)$ \\
\hline 2000 & 376 & 15.43 & 1,281 & 9.68 & Reject $\mathrm{H}_{\mathrm{o}}(p=0.0017)$ \\
\hline 2001 & 424 & 15.57 & 1,133 & 10.41 & Reject $\mathrm{H}_{\mathrm{o}}(p=0.0051)$ \\
\hline 2002 & 438 & 15.07 & 1,187 & 9.27 & Reject $\mathrm{H}_{\mathrm{o}}(p=0.0008)$ \\
\hline 2003 & 398 & 16.83 & 1,330 & 10.60 & Reject $\mathrm{H}_{\mathrm{o}}(p=0.0008)$ \\
\hline 2004 & 249 & 22.18 & 1,453 & 9.91 & Reject $\mathrm{H}_{\mathrm{o}}(p<0.0001)$ \\
\hline 2005 & 223 & 13.90 & 1,430 & 12.45 & Do Not Reject $H_{o}(p=0.5430)$ \\
\hline 2006 & 226 & 22.57 & 1,474 & 13.57 & Reject $\mathrm{H}_{\mathrm{o}}(p=0.0004)$ \\
\hline 2007 & 180 & 21.11 & 1,613 & 16.12 & Do Not Reject $\mathrm{H}_{\mathrm{o}}(p=0.0880)$ \\
\hline \multicolumn{6}{|c|}{$\begin{array}{l}\text { Pearson Chi-Square Test for Independence } \\
\mathrm{H}_{\mathrm{o}} \text { : In the first-time, full-time population of this year, there is no association between } \\
\text { taking the course and graduating in four years. } \\
\mathrm{H}_{\mathrm{a}} \text { : In the first-time, full-time population of this year, there is an association between } \\
\text { taking the course and graduating in four years. }\end{array}$} \\
\hline
\end{tabular}




\begin{tabular}{|c|c|c|c|c|c|}
\hline \multicolumn{6}{|c|}{$\begin{array}{l}\text { TABLE } 2 \\
\text { Five Year Graduation Rates for FTFT Students }\end{array}$} \\
\hline \multirow[t]{2}{*}{ Year } & \multicolumn{2}{|c|}{$\begin{array}{l}\text { Students Who Took the } \\
\text { Library Course }\end{array}$} & \multicolumn{2}{|c|}{$\begin{array}{l}\text { Students Who Did Not } \\
\text { Take the Library Course }\end{array}$} & \multirow{2}{*}{$\begin{array}{c}\text { Statistical Analysis } \\
p=\text { Probability of Wrongly } \\
\text { Rejecting } \mathrm{H}_{\mathrm{o}} \text { When It Is True }\end{array}$} \\
\hline & Population & $\begin{array}{l}\text { Graduation } \\
\text { Rate }(\%)\end{array}$ & Population & $\begin{array}{l}\text { Graduation } \\
\text { Rate }(\%)\end{array}$ & \\
\hline 1999 & 295 & 26.10 & 1,303 & 20.87 & Reject $\mathrm{H}_{\mathrm{o}}(p<0.0001)$ \\
\hline 2000 & 376 & 46.81 & 1,281 & 22.95 & Reject $\mathrm{H}_{\mathrm{o}}(p<0.0001)$ \\
\hline 2001 & 424 & 47.88 & 1,133 & 23.48 & Reject $\mathrm{H}_{\mathrm{o}}(p<0.0001)$ \\
\hline 2002 & 438 & 38.81 & 1,187 & 20.56 & Reject $\mathrm{H}_{\mathrm{o}}(p<0.0001)$ \\
\hline 2003 & 398 & 41.71 & 1,330 & 25.71 & Reject $\mathrm{H}_{\mathrm{o}}(p<0.0001)$ \\
\hline 2004 & 249 & 43.95 & 1,453 & 25.40 & Reject $\mathrm{H}_{\mathrm{o}}(p<0.0001)$ \\
\hline 2005 & 223 & 41.26 & 1,430 & 28.32 & Reject $\mathrm{H}_{\mathrm{o}}(p<0.0001)$ \\
\hline 2006 & 226 & 42.92 & 1,474 & 29.58 & Reject $\mathrm{H}_{\mathrm{o}}(p<0.0001)$ \\
\hline \multicolumn{6}{|c|}{$\begin{array}{l}\text { Pearson Chi-Square Test for Independence } \\
\mathrm{H}_{\mathrm{o}} \text { : In the first-time, full-time population of this year, there is no association between } \\
\text { taking the course and graduating in five years. } \\
\mathrm{H}_{\mathrm{a}} \text { : In the first-time, full-time population of this year, there is an association between } \\
\text { taking the course and graduating in five years. }\end{array}$} \\
\hline
\end{tabular}

effect, students in the library course were graduating at significantly higher rates for all terms five years or longer. Perhaps the most startling result of all had to do with the total graduation rates. For the 15,012 FTFT students who were considered in this study, 56 percent of those who took the library course graduated before summer 2011, while only 30 percent of those who did not take the course graduated.

The analysis of the college graduation GPAs also revealed some surprising

\begin{tabular}{|c|c|c|c|c|c|}
\hline \multicolumn{6}{|c|}{$\begin{array}{c}\text { TABLE } 3 \\
\text { Six Year Graduation Rates for FTFT Students }\end{array}$} \\
\hline \multirow[t]{2}{*}{ Year } & \multicolumn{2}{|c|}{$\begin{array}{l}\text { Students Who Took the } \\
\text { Library Course }\end{array}$} & \multicolumn{2}{|c|}{$\begin{array}{l}\text { Students Who Did Not } \\
\text { Take the Library Course }\end{array}$} & \multirow{2}{*}{$\begin{array}{c}\text { Statistical Analysis } \\
p=\text { Probability of Wrongly } \\
\text { Rejecting } \mathrm{H}_{\mathrm{o}} \text { When It Is True }\end{array}$} \\
\hline & Population & $\begin{array}{l}\text { Graduation } \\
\text { Rate }(\%)\end{array}$ & Population & $\begin{array}{l}\text { Graduation } \\
\text { Rate }(\%)\end{array}$ & \\
\hline 1999 & 295 & 59.66 & 1,303 & 25.33 & Reject $\mathrm{H}_{\mathrm{o}}(p<0.0001)$ \\
\hline 2000 & 376 & 57.45 & 1,281 & 27.32 & Reject $\mathrm{H}_{\mathrm{o}}(p<0.0001)$ \\
\hline 2001 & 424 & 56.37 & 1,133 & 28.77 & Reject $\mathrm{H}_{\mathrm{o}}(p<0.0001)$ \\
\hline 2002 & 438 & 48.17 & 1,187 & 25.36 & Reject $\mathrm{H}_{\mathrm{o}}(p<0.0001)$ \\
\hline 2003 & 398 & 53.27 & 1,330 & 31.35 & Reject $\mathrm{H}_{\mathrm{o}}(p<0.0001)$ \\
\hline 2004 & 249 & 54.03 & 1,453 & 31.59 & Reject $\mathrm{H}_{\mathrm{o}}(p<0.0001)$ \\
\hline 2005 & 223 & 55.61 & 1,430 & 35.52 & Reject $\mathrm{H}_{\mathrm{o}}(p<0.0001)$ \\
\hline \multicolumn{6}{|c|}{$\begin{array}{l}\text { Pearson Chi-Square Test for Independence } \\
\mathrm{H}_{\mathrm{o}} \text { : In the first-time, full-time population of this year, there is no association between } \\
\text { taking the course and graduating in six years. } \\
\mathrm{H}_{\mathrm{a}} \text { : In the first-time, full-time population of this year, there is an association between } \\
\text { taking the course and graduating in six years. }\end{array}$} \\
\hline
\end{tabular}




\begin{tabular}{|c|c|c|c|c|c|}
\hline \multicolumn{6}{|c|}{$\begin{array}{c}\text { TABLE } 4 \\
\text { Total Graduation Rates for FTFT Students }\end{array}$} \\
\hline \multirow[t]{2}{*}{ Year } & \multicolumn{2}{|c|}{$\begin{array}{c}\text { Students Who Took the } \\
\text { Library Course }\end{array}$} & \multicolumn{2}{|c|}{$\begin{array}{l}\text { Students Who Did Not } \\
\text { Take the Library Course }\end{array}$} & \multirow{2}{*}{$\begin{array}{c}\text { Statistical Analysis } \\
p=\text { Probability of Wrongly } \\
\text { Rejecting } \mathrm{H}_{\mathrm{o}} \text { When It Is True }\end{array}$} \\
\hline & Population & $\begin{array}{l}\text { Graduation } \\
\text { Rate }(\%)\end{array}$ & Population & $\begin{array}{l}\text { Graduation } \\
\text { Rate }(\%)\end{array}$ & \\
\hline 1999 & 295 & 68.14 & 1,303 & 29.24 & Reject $\mathrm{H}_{\mathrm{o}}(p<0.0001)$ \\
\hline 2000 & 376 & 65.96 & 1,281 & 31.46 & Reject $\mathrm{H}_{\mathrm{o}}(p<0.0001)$ \\
\hline 2001 & 424 & 63.44 & 1,133 & 33.63 & Reject $\mathrm{H}_{\mathrm{o}}(p<0.0001)$ \\
\hline 2002 & 438 & 53.65 & 1,187 & 29.06 & Reject $\mathrm{H}_{\mathrm{o}}(p<0.0001)$ \\
\hline 2003 & 398 & 56.78 & 1,330 & 34.89 & Reject $\mathrm{H}_{\mathrm{o}}(p<0.0001)$ \\
\hline 2004 & 249 & 57.26 & 1,453 & 34.48 & Reject $\mathrm{H}_{\mathrm{o}}(p<0.0001)$ \\
\hline 2005 & 223 & 55.61 & 1,430 & 35.52 & Reject $\mathrm{H}_{\mathrm{o}}(p<0.0001)$ \\
\hline 2006 & 226 & 42.92 & 1,474 & 29.58 & Reject $\mathrm{H}_{\mathrm{o}}(p<0.0001)$ \\
\hline 2007 & 180 & 21.11 & 1,613 & 16.12 & Do Not Reject $\mathrm{H}_{\mathrm{o}}(p=0.0880)$ \\
\hline \multicolumn{6}{|c|}{$\begin{array}{l}\text { Pearson Chi-Square Test for Independence } \\
\mathrm{H}_{\mathrm{o}} \text { : In the first-time, full-time population of this year, there is no association between } \\
\text { taking the course and graduating from college. } \\
\mathrm{H}_{\mathrm{a}} \text { : In the first-time, full-time population of this year, there is an association between } \\
\text { taking the course and graduating from college. }\end{array}$} \\
\hline
\end{tabular}

\begin{tabular}{|c|c|c|c|c|c|}
\hline \multicolumn{6}{|c|}{$\begin{array}{c}\text { TABLE } 5 \\
\begin{array}{c}\text { College Graduation GPAs for FTFT Students Who Graduated } \\
\text { before Summer } 2011\end{array}\end{array}$} \\
\hline \multirow[t]{2}{*}{ Year } & \multicolumn{2}{|c|}{$\begin{array}{l}\text { Students Who Took } \\
\text { the Library Course }\end{array}$} & \multicolumn{2}{|c|}{$\begin{array}{l}\text { Students Who Did Not } \\
\text { Take the Library Course }\end{array}$} & \multirow{2}{*}{$\begin{array}{c}\text { Statistical Analysis } \\
p=\text { Probability of Wrongly } \\
\text { Rejecting } \mathrm{H}_{\mathrm{o}} \text { When It Is True }\end{array}$} \\
\hline & $\begin{array}{l}\text { Number } \\
\text { of Grads }\end{array}$ & $\begin{array}{l}\text { Average } \\
\text { GPA }\end{array}$ & $\begin{array}{l}\text { Number } \\
\text { of Grads }\end{array}$ & $\begin{array}{l}\text { Average } \\
\text { GPA }\end{array}$ & \\
\hline 1999 & 201 & 2.89 & 381 & 3.00 & Reject $\mathrm{H}_{\mathrm{o}}(p=0.0047)$ \\
\hline 2000 & 248 & 2.98 & 403 & 3.06 & Reject $\mathrm{H}_{\mathrm{o}}(p=0.0370)$ \\
\hline 2001 & 269 & 3.08 & 381 & 3.04 & Do Not Reject $\mathrm{H}_{\mathrm{o}}(p=0.2570)$ \\
\hline 2002 & 235 & 3.02 & 345 & 3.09 & Do Not Reject $\mathrm{H}_{\mathrm{o}}(p=0.0540)$ \\
\hline 2003 & 226 & 3.07 & 464 & 3.08 & Do Not Reject $\mathrm{H}_{\mathrm{o}}(p=0.7046)$ \\
\hline 2004 & 142 & 3.09 & 501 & 3.08 & Do Not Reject $\mathrm{H}_{\mathrm{o}}(p=0.7599)$ \\
\hline 2005 & 124 & 3.05 & 508 & 3.10 & Do Not Reject $\mathrm{H}_{\mathrm{o}}(p=0.2594)$ \\
\hline 2006 & 97 & 3.17 & 436 & 3.14 & Do Not Reject $\mathrm{H}_{\mathrm{o}}(p=0.4246)$ \\
\hline 2007 & 38 & 3.23 & 260 & 3.34 & Do Not Reject $H_{o}(p=0.1021)$ \\
\hline \multicolumn{6}{|c|}{$\begin{array}{l}\text { Two Sample z-Test for Difference between Means } \\
\mathrm{H}_{\mathrm{o}} \text { : For the FTFT population of this year, there is no difference in the average college } \\
\text { graduation GPA of students who took the class and students who did not take the class. } \\
\mathrm{H}_{\mathrm{a}} \text { : For the FTFT population of this year, there is a difference in the average college } \\
\text { graduation GPA of students who took the class and students who did not take the class. }\end{array}$} \\
\hline
\end{tabular}


results. The null hypothesis was only rejected for two of the nine years (see table 5). That is, for seven of the nine years, there was no significant difference in college graduation GPAs between students who took the course and those who did not. Interestingly, in the two years that did show a significant difference (1999 and 2000), the LIBR1101 students GPAs had lower GPAs than those who did not take the class. Hence, during the study's time frame, more LIBR 1101 students were graduating, even when they had average lower GPAs at the end of their collegiate career.

The predictor tests for ACT, SATV, SATM, and high school GPAs were also illuminating. There was a difference in the average ACT scores for three of the nine years. For these three years, the average ACT score for students in the course was lower than students not in the course (see table 7). There was a difference in the average SATV score for four of the nine years (see table 8). Again, this difference in each case was because the average score for students in the course was significantly lower than students without the course. There was a difference in the average SATM score for three of the nine years (see table 9). Here too, the pattern held, with students in the course scoring lower on average than students without the course. Finally, there was a difference in the average high school GPA for three of the nine years (see table 6). Intriguingly, here the pattern broke. In these three cases (2000, 2001, and 2006), the high school GPA for library students was actually higher than those without the class.

\section{Discussion}

Because this is an observational study, librarians must be cautious in generalizing its results. The population of LIBR 1101 students was not randomly selected from the total FTFT population. The students themselves were the ones to choose which cohort they would be in when they opted to take the course. In addition, the FTFT population for each year was not randomly selected from the

\begin{tabular}{|c|c|c|c|c|c|}
\hline \multicolumn{6}{|c|}{$\begin{array}{c}\text { TABLE } 6 \\
\text { High School Graduation GPAs for FTFT Students }\end{array}$} \\
\hline \multirow[t]{2}{*}{ Year } & \multicolumn{2}{|c|}{$\begin{array}{l}\text { Students Who Took } \\
\text { the Library Course }\end{array}$} & \multicolumn{2}{|c|}{$\begin{array}{l}\text { Students Who Did Not } \\
\text { Take the Library Course }\end{array}$} & \multirow{2}{*}{$\begin{array}{c}\text { Statistical Analysis } \\
p=\text { Probability of Wrongly } \\
\text { Rejecting } \mathrm{H}_{\mathrm{o}} \text { When It Is True }\end{array}$} \\
\hline & Population & $\begin{array}{l}\text { Average } \\
\text { GPA }\end{array}$ & Population & $\begin{array}{l}\text { Average } \\
\text { GPA }\end{array}$ & \\
\hline 1999 & 295 & 2.90 & 1,303 & 2.85 & Do Not Reject $\mathrm{H}_{\mathrm{o}}(p=0.1408)$ \\
\hline 2000 & 376 & 3.02 & 1,281 & 2.94 & Reject $\mathrm{H}_{\mathrm{o}}(p=0.0081)$ \\
\hline 2001 & 424 & 3.06 & 1,133 & 2.96 & Reject $H_{o}(p=0.0009)$ \\
\hline 2002 & 438 & 3.02 & 1,187 & 2.97 & Do Not Reject $\mathrm{H}_{\mathrm{o}}(p=0.0702)$ \\
\hline 2003 & 398 & 3.01 & 1,330 & 2.95 & Do Not Reject $\mathrm{H}_{\mathrm{o}}(p=0.0556)$ \\
\hline 2004 & 249 & 2.97 & 1,453 & 2.97 & Do Not Reject $\mathrm{H}_{\mathrm{o}}(p=0.9965)$ \\
\hline 2005 & 223 & 3.01 & 1,430 & 3.01 & Do Not Reject $\mathrm{H}_{\mathrm{o}}(p=0.9467)$ \\
\hline 2006 & 226 & 3.07 & 1,474 & 2.99 & Reject $\mathrm{H}_{\mathrm{o}}(p=0.0191)$ \\
\hline 2007 & 180 & 3.06 & 1,613 & 3.05 & Do Not Reject $\mathrm{H}_{\mathrm{o}}(p=0.7387)$ \\
\hline \multicolumn{6}{|c|}{$\begin{array}{l}\text { Two Sample z-Test for Difference between Means } \\
\mathrm{H}_{\mathrm{o}} \text { : For the FTFT population of this year, there is no difference in the average high school } \\
\text { graduation GPA of students who took the class and students who did not take the class. } \\
\mathrm{H}_{\mathrm{a}} \text { : For the FTFT population of this year, there is a difference in the average high school } \\
\text { graduation GPA of students who took the class and students who did not take the class. }\end{array}$} \\
\hline
\end{tabular}




\begin{tabular}{|c|c|c|c|c|c|}
\hline \multicolumn{6}{|c|}{$\begin{array}{c}\text { TABLE } 7 \\
\text { ACT Scores for FTFT Students }\end{array}$} \\
\hline \multirow[t]{2}{*}{ Year } & \multicolumn{2}{|c|}{$\begin{array}{l}\text { Students Who Took } \\
\text { the Library Course }\end{array}$} & \multicolumn{2}{|c|}{$\begin{array}{l}\text { Students Who Did Not } \\
\text { Take the Library Course }\end{array}$} & \multirow{2}{*}{$\begin{array}{c}\text { Statistical Analysis } \\
p=\text { Probability of Wrongly } \\
\text { Rejecting } \mathrm{H}_{\mathrm{o}} \text { When It Is True }\end{array}$} \\
\hline & Population & $\begin{array}{l}\text { Average } \\
\text { Score }\end{array}$ & Population & $\begin{array}{l}\text { Average } \\
\text { Score }\end{array}$ & \\
\hline 1999 & 295 & 19.06 & 1,303 & 19.26 & Do Not Reject $\mathrm{H}_{\mathrm{o}}(p=0.3586)$ \\
\hline 2000 & 376 & 18.58 & 1,281 & 19.84 & Reject $\mathrm{H}_{\mathrm{o}}(p<0.0001)$ \\
\hline 2001 & 424 & 19.92 & 1,133 & 20.06 & Do Not Reject $\mathrm{H}_{\mathrm{o}}(p=0.4238)$ \\
\hline 2002 & 438 & 20.49 & 1,187 & 20.57 & Do Not Reject $\mathrm{H}_{\mathrm{o}}(p=0.6189)$ \\
\hline 2003 & 398 & 20.15 & 1,330 & 20.69 & Reject $\mathrm{H}_{\mathrm{o}}(p=0.0014)$ \\
\hline 2004 & 249 & 20.20 & 1,453 & 20.43 & Do Not Reject $\mathrm{H}_{\mathrm{o}}(p=0.2077)$ \\
\hline 2005 & 223 & 20.64 & 1,430 & 20.36 & Do Not Reject $H_{o}(p=0.2127)$ \\
\hline 2006 & 226 & 19.59 & 1,474 & 20.44 & Reject $\mathrm{H}_{\mathrm{o}}(p<0.0001)$ \\
\hline 2007 & 180 & 20.24 & 1,613 & 20.16 & Do Not Reject $\mathrm{H}_{\mathrm{o}}(p=0.7401)$ \\
\hline \multicolumn{6}{|c|}{$\begin{array}{l}\text { Two Sample z-Test for Difference between Means } \\
\mathrm{H}_{\mathrm{o}} \text { : For the FTFT population of this year, there is no difference in the average ACT scores } \\
\text { of students who took the class and students who did not take the class. } \\
\mathrm{H}_{\mathrm{a}} \text { : For the FTFT population of this year, there is a difference in the average ACT scores } \\
\text { of students who took the class and students who did not take the class. }\end{array}$} \\
\hline
\end{tabular}

\begin{tabular}{|c|c|c|c|c|c|}
\hline \multicolumn{6}{|c|}{$\begin{array}{c}\text { TABLE } 8 \\
\text { SATV Scores for FTFT Students }\end{array}$} \\
\hline \multirow[t]{2}{*}{ Year } & \multicolumn{2}{|c|}{$\begin{array}{l}\text { Students Who Took } \\
\text { the Library Course }\end{array}$} & \multicolumn{2}{|c|}{$\begin{array}{l}\text { Students Who Did Not } \\
\text { Take the Library Course }\end{array}$} & \multirow{2}{*}{$\begin{array}{l}\text { Statistical Analysis } \\
p=\text { Probability of Wrongly } \\
\text { Rejecting } \mathrm{H}_{\mathrm{o}} \text { When It Is True }\end{array}$} \\
\hline & Population & $\begin{array}{l}\text { Average } \\
\text { Score }\end{array}$ & Population & $\begin{array}{l}\text { Average } \\
\text { Score }\end{array}$ & \\
\hline 1999 & 295 & 476.79 & 1,303 & 488.36 & Reject $\mathrm{H}_{\mathrm{o}}(p=0.0139)$ \\
\hline 2000 & 376 & 480.81 & 1,281 & 497.41 & Reject $\mathrm{H}_{\mathrm{o}}(p<0.0001)$ \\
\hline 2001 & 424 & 498.32 & 1,133 & 503.81 & Do Not Reject $\mathrm{H}_{\mathrm{o}}(p=0.1134)$ \\
\hline 2002 & 438 & 499.98 & 1,187 & 508.04 & Reject $\mathrm{H}_{\mathrm{o}}(p=0.0234)$ \\
\hline 2003 & 398 & 508.01 & 1,330 & 507.41 & Do Not Reject $\mathrm{H}_{\mathrm{o}}(p=0.8695)$ \\
\hline 2004 & 249 & 508.39 & 1,453 & 507.48 & Do Not Reject $\mathrm{H}_{\mathrm{o}}(p=0.8188)$ \\
\hline 2005 & 223 & 506.82 & 1,430 & 515.84 & Reject $\mathrm{H}_{\mathrm{o}}(p=0.0467)$ \\
\hline 2006 & 226 & 500.86 & 1,474 & 507.85 & Do Not Reject $\mathrm{H}_{\mathrm{o}}(p=0.1114)$ \\
\hline 2007 & 180 & 513.06 & 1,613 & 508.29 & Do Not Reject $\mathrm{H}_{\mathrm{o}}(p=0.3277)$ \\
\hline \multicolumn{6}{|c|}{$\begin{array}{l}\text { Two Sample z-Test for Difference between Means } \\
\mathrm{H}_{\mathrm{o}} \text { : For the FTFT population of this year, there is no difference in the average SATV } \\
\text { scores of students who took the class and students who did not take the class. } \\
\mathrm{H}_{\mathrm{a}} \text { : For the FTFT population of this year, there is a difference in the average SATV scores } \\
\text { of students who took the class and students who did not take the class. }\end{array}$} \\
\hline
\end{tabular}




\begin{tabular}{|c|c|c|c|c|c|}
\hline \multicolumn{6}{|c|}{$\begin{array}{c}\text { TABLE } 9 \\
\text { SATM Scores for FTFT Students }\end{array}$} \\
\hline \multirow[t]{2}{*}{ Year } & \multicolumn{2}{|c|}{$\begin{array}{l}\text { Students Who Took } \\
\text { the Library Course }\end{array}$} & \multicolumn{2}{|c|}{$\begin{array}{l}\text { Students Who Did Not } \\
\text { Take the Library Course }\end{array}$} & \multirow{2}{*}{$\begin{array}{c}\text { Statistical Analysis } \\
p=\text { Probability of Wrongly } \\
\text { Rejecting } \mathrm{H}_{\mathrm{o}} \text { When It Is True }\end{array}$} \\
\hline & Population & $\begin{array}{l}\text { Average } \\
\text { Score }\end{array}$ & Population & $\begin{array}{l}\text { Average } \\
\text { Score }\end{array}$ & \\
\hline 1999 & 295 & 474.81 & 1,303 & 476.13 & Do Not Reject $\mathrm{H}_{\mathrm{o}}(p=0.7636)$ \\
\hline 2000 & 376 & 479.27 & 1,281 & 489.24 & Reject $\mathrm{H}_{\mathrm{o}}(p=0.0119)$ \\
\hline 2001 & 424 & 496.97 & 1,133 & 496.90 & Do Not Reject $\mathrm{H}_{\mathrm{o}}(p=0.9852)$ \\
\hline 2002 & 438 & 496.60 & 1,187 & 504.12 & Reject $\mathrm{H}_{\mathrm{o}}(p=0.0379)$ \\
\hline 2003 & 398 & 502.23 & 1,330 & 498.89 & Do Not Reject $\mathrm{H}_{\mathrm{o}}(p=0.3671)$ \\
\hline 2004 & 249 & 497.10 & 1,453 & 497.93 & Do Not Reject $\mathrm{H}_{\mathrm{o}}(p=0.8510)$ \\
\hline 2005 & 223 & 498.28 & 1,430 & 506.81 & Do Not Reject $\mathrm{H}_{\mathrm{o}}(p=0.0622)$ \\
\hline 2006 & 226 & 495.10 & 1,474 & 501.73 & Do Not Reject $\mathrm{H}_{\mathrm{o}}(p=0.1273)$ \\
\hline 2007 & 180 & 487.76 & 1,613 & 503.57 & Reject $\mathrm{H}_{\mathrm{o}}(p=0.0009)$ \\
\hline \multicolumn{6}{|c|}{$\begin{array}{l}\text { Two Sample z-Test for Difference between Means } \\
\mathrm{H}_{\mathrm{o}} \text { : For the FTFT population of this year, there is no difference in the average SATM } \\
\text { scores of students who took the class and students who did not take the class. } \\
\mathrm{H}_{\mathrm{a}}: \text { For the FTFT population of this year, there is a difference in the average SATM scores } \\
\text { of students who took the class and students who did not take the class. }\end{array}$} \\
\hline
\end{tabular}

total population of students at the school. Here too, student behavior determined whether or not they were eligible for the study population.

Even so, there are some intriguing trends that bear further discussion. First, students who take the library credit course at UWG are graduating at significantly higher rates than students who do not take the course. Overall, they are completing college at almost double the rate that students without the class are graduating. This massive jump cannot be accounted for by the standard predictor tests for success in college (the ACT and SAT). In both cases, students in the class actually averaged scores that were the same or a little lower than scores of students who never took the course. High school GPAs seem to be a somewhat better indicator of success, but there were only significant differences in the average GPAs of the cohorts in three of the nine years. The other two-thirds of the study showed no significant change. A 26 percent increase in college graduation rates cannot reasonably be explained by a 2 percent jump in high school GPAs.

That is not to say that the library course is the cause for these students' success. These correlative studies only examine a few very specific attributes of the FTFT populations. There is no attempt to account for race, gender, economic level, major, or any other factor that has been shown to affect collegiate success. There is no determination of when students may have taken the course during their time at the school, nor whether or not they used techniques and information from the library course in their other classes.

There also should be an accounting for the differing trends in high school and college graduation GPAs. For all nine years, the high school GPAs for students in the library course were higher than or equivalent to the high school GPAs for students without the library course. Yet, the college graduation GPAs show the opposite trend. Graduation GPAs oscillate more wildly and are in fact lower for LIBR 1101 students six out of the nine years. In 
fact, the overall 2 percent increase in high school GPAs for library students becomes an overall 2 percent decrease in college graduation GPAs. Does this mean the library course was hurting its students' GPAs? Actually, this might be an artifact of the 26 percent jump in graduation rates. If we assume that students with higher GPAs are more likely to graduate, then a higher graduation rate will include more students with lower GPAs. In that case, this lower GPA is a good sign that the library is helping students to graduate who might otherwise have failed to do so. However, this point is supposition. The study, as designed, cannot support this argument.

\section{Conclusions}

The necessary methodology of the study, namely a nonrandom, nonrepresentative sample with a limited number of controls, somewhat limits its usefulness in statistical generalizing about the value of library instruction as a whole. Because the course was self-selected, and the samples were not random, it is possible that these results are indicative of something other than the effect of library instruction. However, this study does have one very important trait: scale. Fifteen thousand students taking one course over a twelve-year period were included. Though the exact curricula evolved as both students and technology changed, the course always focused on the core values of finding, evaluating, and effectively and ethically using information. Regardless of how the course was offered, who was teaching it, or what its precise objectives were, students who took the class still graduated from college at higher rates than those who did not take the class.

The ACRL report The Value of Academic Libraries urged its members to work toward a research agenda that would establish the value of academic libraries in measures such as graduation rates. ${ }^{23}$ They encouraged librarians to report their results to their school and their colleagues, even if those results were not ideal, so that the profession could develop a convincing body of evidence. ${ }^{24}$ With that in mind, this study suggests several interesting inferences that could be vital to the future of libraries. Library instruction has a lasting and measurable impact on student graduation rates. Library instruction might help those students who are not predicted to be as successful at college to actually graduate. Libraries can measure their effectiveness in quantifiable ways that are meaningful and relevant to their campus. While this study does not, and cannot, definitively show these conclusions, it may perhaps provide one of the many beginnings of the profession's body of evidence.

This study prompts many additional questions. Do students at other institutions experience a similar jump in success rates after taking a library credit course? What is the best time in a student's collegiate career to take a library course? Is the course more effective when delivered face to face or in an online format? Does the library course help at-risk students more than honors students?

As politicians push for more performance-based funding, and campuses push for more demonstrable and quantitative success, such studies will become increasingly important to academic libraries. While no study can ever prove that the reason a specific student graduated was because he or she took a certain class or attended a certain library workshop, by gathering together an increasing number of suggestive correlative studies, libraries can begin to establish their place in each student's success.

\section{Notes}

1. Association of College and Research Libraries. Value of Academic Libraries: A

Comprehensive Research Review and Report. Researched by Megan Oakleaf. Chicago: Association 
of College and Research Libraries, 2010, 25.

2. Ibid., 106-08.

3. Richard J. Wood, "The Impact of a Library Research Course on Students at Slippery Rock University," Journal of Academic Librarianship 10, no. 5 (1984): 278-84.

4. Carol Anne Germain, Trudi E. Jacobson, and Sue A Kaczor, "A Comparison of the Effectiveness of Presentation Formats For Instruction: Teaching First-Year Students," College $\mathcal{E}$ Research Libraries 61, no. 1 (2000): 65-72.

5. Shannon M. Staley, Nicole A. Branch, and Tom L. Hewitt, "Standardized Library Instruction Assessment: An Institution-Specific Approach," Information Research: An International Electronic Journal 15, no. (2010): 22.

6. Bonnie J.M Swoger, "Closing the Assessment Loop Using Pre- and Post-Assessment," Reference Services Review 39, no. 2 (2011): 244-59.

7. Kathleen Joswick, "Library Materials Use by College Freshmen: A Citation Analysis of Composition Papers," College \& Undergraduate Libraries 1, no.1 (1994): 43-65.

8. Karen Hovde, "Check the Citation: Library Instruction and Student Paper Bibliographies," Research Strategies 17, no. 1 (2000): 3-9.

9. Kate Silfen and Karen Zgoda, "Evidence-Based Practice and Information Literacy in Social Work: An Assessment of Students' Reference Lists," Behavioral \& Social Sciences Librarian 27, no. 2 (2008): 104-15.

10. Amy Brunvand and Tatiana Pashkova-Balkenhol, "Undergraduate Use of Government Information: What Citation Studies Tell Us about Instruction Strategies," portal: Libraries and the Academy 8, no. 2 (2008): 197-209.

11. Vickery Kaye Lebbin, "Student Perceptions on the Long-Range Value of Information Literacy Instruction through a Learning Community," Research Strategies 20, no. 3 (2005): 204-18.

12. Alice L. Daugherty and Michael F. Russo, "An Assessment of the Lasting Effects of a StandAlone Information Literacy Course: The Students' Perspective," Journal of Academic Librarianship 37, no. 4 (2011): 319-26.

13. Ibid.

Roland Person, "Long-Term Evaluation of Bibliographic Instruction: Lasting Encouragement," College $\mathcal{E}$ Research Libraries 42, no. 1 (1981): 19-25.

14. Larry Hardesty, Nicholas P. Lovrich Jr., and James Mannon, "Library-Use Instruction: Assessment of Long-Term Effects," College E Research Libraries 43, no. 1 (1982): 38-46.

15. Shun Han Rebekah Wong and Dianne Cmor, "Measuring Association between Library Instruction and Graduation GPA," College \& Research Libraries 72, no. 5 (2011): 464-73.

16. Rui Wang, "The Lasting Impact of a Library Credit Course," portal: Libraries and the Academy 6, no. 1 (2006): 79-92.

17. Ibid.

18. John Cornell Selegean, Martha Lou Thomas, and Marie Louise Richman, "Long-Range

Effectiveness of Library-Use Instruction," College \& Research Libraries 44, no. 6 (1983): 476-80.

19. Ibid.

20. Alan Bailin, Elena Cevallos, and Ann Grafstein, "First-Year Programs and Information Literacy: Challenges and Opportunities." Presentation at the 27th Annual Conference on the First-Year Experience, San Francisco, Calif., Feb. 18, 2008.

21. ACRL, Information Literacy: Competency Standards for Higher Education, 2.

22. ACRL, The Value of Academic Libraries, 93.

23. Ibid. 